\title{
REFLECTIONS ON POLITICS AND CAPITAL AMONG TEA PARTIERS
}

\section{BY THOMAS W. FLEMING}

JOHN:

THAT'S WHAT IT'S ALL ABOUT - IT'S ABOUT FREE TRADE. IT'S ABOUT BUYIN' AND SELLIN' STUFF. [...] AND WE DON'T WANT TO BE FETTERED. IF I TELL YOU THAT THIS WATER IS THE BEST WATER IN ST. CHARLES AND IT'S GONNA COST YOU A BUCK A GLASS [...] AND ACROSS THE STREET THEY'RE GIVIN' IT AWAY FREE ... YOU DIDN'T MIND PAYIN' A DOLLAR A GLASS. [I]T'S ALL ABOT KEEPIN' GOVERNMENT OUT OF YOUR LIFE, BECAUSE PEOPLE, GIVEN FREEDOM, WILL BUY AND SELL AND CREATE COMMERCE. AND WHAT ELSE IS THERE, YOU KNOW?

$\mathrm{J}$ ohn - a late-50's Tea Party leader and business owner in St Charles, Illinois - used this parable to illustrate the naturalness of capitalist exchange, the productive benefits of 'freedom'. We sat together at lunch in downtown St Charles while he attempted to explain, with sometimes frustrating brevity, what the Tea Party was about. He and his consociates are predominantly small business owners concerned with the unfettered operation of free market principles and the individual's right to engage in it and create capital, believing that only that political reality which best protects this right is the ideal one. For them, this reality is fast receding, being coopted by the 'Left' (variably called 'socialists', 'Marxists', or 'Communists') who - either mistakenly or not - desire control at the expense of individual liberty. Our conversation was punctuated by exemplars of individuals and corporations who, when left to their devices ('unfettered'), reaped the benefits of their labour, but equally by the prognosis that 'what's going on' is quite the opposite - that our rights to create capital are being abrogated. In what follows, I attempt a descriptive and theoretical overview of how we can approach such neoliberal political discourse, and argue (following Marx and Althusser) that how we understand politics in an anthropological sense turns on the self-referential, self-justifying logic of ideology.

Firstly, I will reflect on the sort of reality that John advocates. This end will be descriptive, but there is an important methodological and theoretical point to be made. I take as fundamental the notion that, following Benveniste, it is in and through language that we constitute ourselves as subjects, thereby establishing our subjectivity (1971: 224). I will not analyze Benveniste's claim, but rather presuppose that it is through our (intersubjective) interactions with one another that we constitute subjectivity and, crucially for our analysis, a subjunctive modality (i.e., the way things ought to be). Following Althusser (1977), I take as central the claim that subjectivity (the recognition that you and I are subjects) occurs within ideology. Likewise, it seems uncontroversial to claim that a subjunctive modality necessary for conceptualizing political ends occurs within ideologies. Thus, we might say knowledge about ourselves, our relation to others and - further removed - how the world ought to be, is inherently recursive and reflexive.

Secondly, an anthropological analysis of politics cannot rely on what I call the politics-quaprocess view, that is, the view that politics can be analyzed as sui generis functional institutions that are somehow extrinsic to our interactions and conceptualizations. It seems to me that while 'capitalism' and the 'free market' are fundamental concepts of an ideal political reality to Tea Partiers, how we study them should rest on the recognition that our subjectivity, being in ideology, is what renders any political reality seemingly 'natural'.

The Tea Party is a self-professedly grass-roots political movement in the United States, that started in 2009. As such its constituent Tea Parties vary in size, demographic composition, and in their organizational activities. While loosely organized, the Tea Parties consistently promote a triad of core principles: (1) fiscal responsibility, (2) constitutionally limited government, and (3) open markets. Many Tea Parties also promote what are deemed 'social' values like 'traditional families'. Furthermore, there is a clear distinction between the ideal political reality and the unjust political reality, the just political reality 
being protected by a just political system, such as that conceived by the Founding Fathers. A 'just' political reality is one in which the economic liberties of individuals and organizations of individuals within the free market are maintained. Contrarily, an unjust political reality is one in which individual liberties are abated by corruption, a disequilibrium in the function of the free market, the possibility of which presents a perpetual moral panic due to a perceived devolution into tyranny.

John claims that he 'joined' the Tea Party at the age of 15 when he 'decided to believe in the Constitution'. This is not hyperbolic because there is a sense in which he and others believe in continuity of their political orientations and transcendent values. Despite this 'transcendence', there is difficulty in talking about Tea Party activists as a 'group' on the level of ethnographic fact-finding and anthropological analysis. On the ethnographic level, John, for one, asserts that it is a loose organization, a 'confederation' further subdivided by 'confederations'. Indeed, the Tea Party is not a political party in the traditional sense. Put generally, it is a collection of 'civic organizations' whose aim is to network and educate its membership, increasing its ranks with 'informed voters' so as to influence the political system. The operation of these groups occurs on a local scale, and is usually managed by a few leaders. Meetings of the group occur normally once or twice a month, serving as informational sessions where specialist speakers give talks on politically prescient issues. Other activities include poll watching, marching/canvassing for candidates, holding rallies, public events, and much more.

Importantly, John rejected that the Tea Party is monolithic, instead asserting that its antistructure reveals people acting in their individual capacities as, above all, concerned citizens, 'people on the street'. This requires an anthropological definition of politics that broadly reflects the subjunctive character of political goals (of ideal states of affairs) rather than reflection of process, since it seems clear that 'political activism' involves more than participation in political structures. In one possible definition, politics denotes an activity that is public rather than private, concerns public goals, and involves a differential of power among the individuals of the group in question (Swartz et al 2002: 105). Studying politics thus involves studying the 'processes involved in determining and implementing public goals and in differential achievement and use of power by members of the group concerned with those goals' (Swartz et al 2002: 107).

However, this definition fails to take into account the fact that an understanding of politics should not be simply processual, but effective. While the purpose of Tea Parties is partly to influence the 'process' of the political system through activism, their continued organization and operation owes much more to common concerns among like-minded citizens who are united by a concern for their liberties and the seeming rationality and commonsense of what they advocate. As such, I prefer a broader definition from Latour, where politics is defined as the progressive attainment of a common world (2010: 60). We might conceptualize the goal of Tea Party politics to be a reality constituted by free market principles, which best reflects the natural abilities and rights of individuals.

Whatever we mean by any political activity, at least regarding Western societies, depends on the conceptual distinction between the 'State' and 'civil society'. It is clear that the Tea Partiers make a distinction between (what is currently or potentially) a hegemonic, partied State and the heterogeneous 'grassroots' populace. But how do we make anthropological sense of this and what are the implications? As Marx observed, there is a presupposition that civil society is composed of 'atoms', 'being[s] without relations, self sufficient' (1963: 225), and it is often taken that the State in some way constrains these atoms that comprise civil society. Marx argued this was not the case - the State does not hold together 'atoms' of civil society, but rather the 'atoms' of civil society are the products of 'imagination' (1963: 226). To think otherwise is due to the pretension that, as Chabal and Daloz observed, civil society has been seen in Western society as largely outside of culture, the idea that democratization is necessarily derived from the 'self-acquired power of civil society to check the hegemony of the State' (2006: 219$20)$. Indeed, while the vast assemblages of civil 
society may be defined in contradistinction and by a self-consciousness of relative externality to the State (Bayart 1986: 117), any politico-scientific study ought to take note of this historical particularity of the concept and its semiotic dimensions.

Civil society and the State might be conceptually distinct from an emic perspective, but they cannot be taken as sui generis. They are embedded in the 'social fabric' and embody a particular manifestation of political accountability that is itself historically particular (Chabal 1986: 12). Accountability, to John, rests on the assumption that 'capitalism' and the 'free markets' are fundamentally constitutive of individual liberty, and this influences and underwrites the perceived goals of the Tea Parties. Such principles are coterminous with American values, John suggests:

"Limited government, fiscal responsibility, free enterprise. [...] Not managed enterprise - free enterprise."

"So, why does [the Tea Party] adopt those principles and not others?", I asked.

To which John responded: "Well, those are the principles of the country. The business of the United States is business. That's what the United States is all about."

Accountability vis-a-vis protecting these rights is legitimized by historical or textual reference and by the self-referential nature of ideology. I will address the former now. It is oftentimes held as an ideal that 'informed voters' familiarize themselves with historical and philosophical texts, including the works of the Founding Fathers (the Federalist Papers), classical conservatives (Edmund Burke), and a significant amount of history. Superlative value is placed on history and philosophy, since they claim that the purpose of their organization is to educate and to propagate this information in such a way that it influences the way their members engage in the political system. For example, what is almost unconditionally appropriated by Tea Partiers is the Lockean notion that rights of appropriation are given in nature, elemental in a lex naturalis, and that this provides a basis for arguments for capitalism. Political structures are only second- ary (minimal in comparison) to a pre-existing, transcendent freedom of the individual to engage in capitalist production.

The logic underlying a Lockean conception of property is equally extensible to capital. Marx suggested that capital was historically opposed to landed property, and first took the form of money, and continues to take the form of money which is continually transformed into capital by 'definite processes' (1909: 108). His descriptions of these processes are concise and denote the exchanges by which a free market ought to function on the Tea Party view. The following schemas represent these 'processes', where ' $C$ ' denotes 'commodity', and ' $\mathrm{M}$ ' denotes 'money':

1. C-M-C: selling in order to buy

2. M-C-M: buying in order to sell

2.a M-C: a purchase

2.b C-M: a sale

3. M-M: exchange of money for money the consequence of the transformation, MC-M.

3.a M-M': exchange of money for more money - the consequence of the transformation, M-C-M'

4. M-C-M': buying in order to sell dearer

Whereas schema 1 represents 'simple circulation', where the values attain a status 'independent of their use-values' in the form of money (i.e., 'M') in the form of exchange values (Marx 1909: 112), the last formula is 'buying in order to sell, or, more accurately, buying in order to sell dearer.' The latter represents the 'general formula of capital as it appears prima facie within the sphere of circulation' (Ibid.: 113). If we suppose for the moment that this represents how Tea Partiers conceptualize their engagement in a capitalist economy, the Lockean notion that individuals are disposed to property naturally, in acquiring it and in propagating it - such that it is an inalienable right - is presupposed in the right of individuals to engage in the 'definite processes' behind capitalist production.

I also mentioned the self-referential nature of ideology. I have moved purposefully from John's description of what 'freedom' engenders to a more general analysis of familiar liberal 
economic postulates. Describing the conditions of capitalist production is apt because Marx recognized that productive capacities, our material circumstances, engender ideology; indeed, consciousness can never be 'anything else but their actual life process' and the 'production of ideas' is 'at first directly interwoven with the material activity and the material intercourse' of persons (1963: 89). Moreover, fundamental to ideology is the recognition that its supposed 'practical role', its logic, and 'conditions of existence' are accompanied by a belief in their supposed necessity (Althusser 1977: 230). That is to say, ideology is the lived relation between people and the world, and as such, the 'naturalness' of capitalism, or a particular political structure conducive to it, is sustained because it is subjectively known. Describing and analyzing the beliefs of Tea Partiers cannot be done by taking capitalism or political systems as sui generis sets of laws - explicit symbolizations with explicit meaning - since, following Cohen (1985: 309), boundaries enacted by 'bounded' groups often subsume 'structures' and perhaps even processes, and are integrated into intra-communal communication in reconstituting meaning.

So, the meaning and social significance does not lie in the reality of the 'free market', but in symbolic statements, as Cohen notes, 'designed to perpetuate the boundary' of a community (1985: 309). Indeed, the 'definite processes' characteristic of capitalism are necessary for their ideal political reality, but this necessity cannot be based on points of continuity or discontinuity at the level of objectivity since this is not coterminous with a study of subjective speech acts, of propositions, of the mundane, that is, the purview of ethnographic description and anthropological analysis. Here we should take Benveniste to heart and notice that language is not simply a tool for communication but is the very condition of subjectivity, and it seems, by implication, to show that ideology (assuming it 'interpellates' subjectivity itself) is intrinsically intersubjective.

John's understanding of what the 'free market' and 'capitalism' is and how this relates to his idea of a just political reality is inseparable from the idea of a 'common world', the subjunctive end that reflects his ontology. The point of this reflection, of course, is to notice that talking about 'free markets', 'capitalism' and 'economics', generally, is problematic since what are prima facie objective entities must be taken constitutively as elements of an ideology which determines the limits of subjectivity, of possibility, and the seeming necessity of social (and political) forms. A proper anthropological understanding of politics, however, yields a clearer picture of how they can be analyzed. 遮 
Althusser, L. (1977) For Marx, trans. Ben Brewster. London: Urwin Brothers Limited.

Althusser, L. (2000). 'Ideology Interpellates Individuals as Subjects.' P. 31-38 in P. Du Gay, J. Evans \& P. Redman (eds.), Identity: A Reader. London: Sage.

Bayart, J. (1986) 'Civil Society in Africa.' P. 109-125 in P. Chabal (ed.), Political Domination in Africa: Reflections on the Limits of Power. Cambridge: Cambridge University Press.

Benveniste, E. (1971) 'Subjectivity in Language.' P. 223-30 in Problems in General Linguistics, trans. Mary E. Meek. Coral Gables, FL: University of Miami Press.

Chabal, P. (ed.) (1986) Political Domination in Africa: Reflections on the Limits of Power. Cambridge University Press.

Chabal, P. \& J. Daloz (2006) Culture Troubles: Politics and the Interpretation of Meaning. Chicago: University of Chicago Press.

Cohen, A. P. (1985) 'Symbolism and Social Change: Matters of Life and Death in Whalsay, Shetland.' Man. 20 (2): 307-324.

Latour, B. (2010) On the Modern Cult of the Factish Gods. Durham, NC: Duke University Press.

Marx, K. (1909) Capital: A Critique of Political Economy. Volume I: The Process of Capitalist Production, ed. F. Engels, trans. S. Moore and E. Aveling. Chicago: Charles H. Kerr and Co.

Marx, K. (1963) Karl Marx: Selected Writings in Sociology and Social Philosophy, ed. T. B. Bottomore. Harmondsworth: Penguin.

Swartz, M. J., V. W. Turner, \& A. Tunden (2002) 'Political Anthropology.' P. 102-110 in J. Vincent (ed.), The Anthropology of Politics: A Reader in Ethnography, Theory, and Critique. Malden, MA: Blackwell. 
